\title{
EFFECT OF ORGANIC FERTILIZERS ON BOTANICAL COMPOSITION OF GRASSLAND, HERBAGE YIELD AND QUALITY
}

\author{
MARIE ŠTÝBNAROVÁ*, PAVLÍNA MIČOVÁ, KAREL FIALA, HANA KARABCOVÁ, \\ OLDŘICH LÁTAL, JAN POZDÍŠEK
}

Agrovyzkum Rapotin Ltd.

ŠTÝBNAROVÁ, M. - MIČOVÁ, P. - FIALA, K. - KARABCOVÁ, H. - LÁTAL, O. - POZDÍŠEK, J.: Effect of organic fertilizers on botanical composition of grassland, herbage yield and quality. Agriculture (Pol'nohospodárstvo), vol. 60, 2014, no. 3, pp. 87-97.

The aim of this study was to assess the effects of organic fertilizers (cow manure + dung water; cattle slurry) applied in different annual doses of nitrogen (54, 84 and $120 \mathrm{~kg} / \mathrm{ha}$ ) by different intensities of grassland utilization (extensive - two cuts per year, medium intensive - three cuts per year, intensive - four cuts per year) on percentage of plant functional groups, dry matter yield, and forage quality. The study was performed on small-plot trial over 7 years on moderately moist grassland in the Czech Republic. The proportion of legumes was significantly higher in the treatments fertilized with cow manure + dung-water combined with medium intensive utilization and intensive utilization $(10.2 \%$ and $10.3 \%$, respective1y). Fertilization significantly increased dry matter yields by $51.9 \%$ (cow manure + dung water) and $56 \%$ (cattle slurry) compared with unfertilized controls (4.81 t/ha). Grasslands fertilized with cattle slurry showed significantly higher concentration of crude protein $(142.9 \mathrm{~g} / \mathrm{kg})$ compared with unfertilized $(126.4 \mathrm{~g} / \mathrm{kg})$. Extensive grassland utilization significantly affected the increase of crude fibre concentration (up to $282.1 \mathrm{~g} / \mathrm{kg}$ ), and decrease of the energy value (up to $4.68 \mathrm{MJ} \mathrm{g} / \mathrm{kg}$ of NEL). Organic matter digestibility was also negatively influenced by extensive grassland utilization $(61.0 \%, 65.42 \%$ and $67.44 \%$ for the extensive, medium intensive and intensive utilization, respectively). Our findings suggested that medium intensive and intensive grassland utilization by the organic fertilization, which corresponded to annual doses of nitrogen of 84 and $120 \mathrm{~kg} /$ ha were the most suitable from the viewpoint of animal nutrition.

Key words: dry matter production, herbage quality, permanent grassland, manure, cattle slurry, fertilization

Permanent grasslands are an important part of the landscape in all European countries. In the Czech Republic, permanent grasslands cover a relatively large area of 992 ths ha, which represents $23.47 \%$ of total agricultural land (Czech Statistical Office 2013). They formed and evolved under the influence of abiotic and biotic ecological factors of environment, plus the overwhelming influence of anthropogenic factor. Their importance consists in the ability to conserve biodiversity, reduce environmental pollution, including nitrogen oxide and sulphur in the air and prevent soil erosion. They are also an important source of forage for a large group of ruminants, but only if improvement measures are provided, along with a rational use (Czembor 2013).

As Müller et al. (2005) emphasized, grassland yield and quality is necessary to assess in relation to changes in botanical composition. The plant composition and species richness of permanent grasslands are determined by management practices and site characteristics such as topography, water and nutrient availability, and light conditions (Sebastiá 2004; Tzialla et al. 2006; Wellstein et al. 2007). As a result, high variability is seen in floristic composition of the vegetation and hence the productivity and quality of forage pro-

Mgr. Marie Štýbnarová, PhD. (*Corresponding author), Ing. Pavlína Mičová, Mgr. Karel Fiala, CSc., Mgr. Hana Karabcová, Ing. Oldřich Látal, PhD., Ing. Jan Pozdíšek, CSc., Agrovyzkum Rapotin Ltd., Výzkumníků 267, 78813 Vikýřovice, Czech Republic. E-mail: marie.stybnarova@vuchs.cz 
duced from these categories of agricultural land (Criste et al. 2013).

The productive potential and quality of permanent grasslands could be increased by different fertilization regimes and types of mineral/organic fertilizers. A typical characteristic of fertilizers is that they affect (directly and indirectly) the growth and development of plants (Pozdíšek et al. 2008). Freely available chemical fertilizers over the past half-century gave rise to a period in which efficient nutrient recycling was not prioritized. However, the emphasis on organic fertilizers as a nutrient resource has been re-established following recent increases in fertilizer prices and the increased focus on manure management within European Union (EU) and national environmental policies (Lalor et al. 2012).

Organic agriculture relies on ecosystem management and ecological processes rather than on the external flow of agricultural inputs (Foissy et al. 2013). Synthetic inputs are replaced with site-specific management practices to balance input and output nutrients to ensure short-term productivity and long-term sustainability. Hence, organic fertilizers are the irreplaceable foundation for rational agriculture. If applied rationally to grasslands, they can entirely replace mineral fertilizers. In addition, organic fertilizers support soil fertility and have other positive effects (Samuil et al. 2009). Cattle slurry, in particular, is a commonly used fertilizer in many countries, and its effect on grassland has been studied (e.g. Liu et al. 2010; Lalor et al. 2012; Duffková \& Libichová 2013).

In the Czech Republic, the systematic utilization of organic fertilizers in permanent grasslands is not common, because of their preferred application in intensive arable crops; however, their importance progressively develops mainly in connection with the development of the organic sector, which induces a spatial decoupling of livestock and crop production. Existing methodological recommendations for the application of organic fertilizers in the Czech Republic do not take into account many important criteria such as type of fertilizer and its recommended dose in relation to type of the grassland, altitude or time of application. Long-term experience from other countries (particularly Austria) is used in this issue. Experimental research is therefore necessary to elucidate this knowledge for Czech local conditions.
The objective of this study was to evaluate how are the botanical composition and the forage yield and quality of permanent grassland influenced by different applications of organic fertilizers (cow manure + dung water; cattle slurry) on the basiss of the experimental research conducted in the Czech Republic.

\section{MATERIAL AND METHODS}

\section{Study site}

A long-term small plot experiment (one plot size: $12.5 \mathrm{~m}^{2}$ ) in completely randomized blocks with four replicates was investigated during 2005-2011 on permanent grassland in the locality of Rapotín $\left(50^{\circ} 00^{\prime} 32^{\prime \prime} \mathrm{N}\right.$ and $\left.17^{\circ} 00^{\prime} 83^{\prime \prime} \mathrm{E}\right)$. The experimental site is situated at $390 \mathrm{~m}$ above sea level on the east decline (with $5.1-6.2^{\circ}$ declination) in a moderately warm region without temperature extremes (Quitt 1971). Average annual temperature is $7.7^{\circ} \mathrm{C}$ and annual precipitation $693 \mathrm{~mm}$. Further meteorological data are given in Table 1. The soil is sandy-loam, Haplic Cambisol with horizons $\mathrm{Am}-\mathrm{Bv}-\mathrm{Bv} / \mathrm{Cc}-\mathrm{Cc}$ (classification system according to IUSS Working Group WRB, 2006). Table 2 shows agro-chemical parameters of soil horizons determined in spring 2005. The vegetation of the experimental pasture was classified as Cynosurion with some elements of Arrhenatherion (Moravec et al. 1995). Before the experiment setup, the grassland had been used for cattle grazing for over 30 years.

\section{Treatments}

Two types of organic fertilizers were applied during 2005-2011: (M) combination of cow manure + dung water and (S) cattle slurry. Organic fertilizers were used in annual doses of nitrogen: 54, 84 and $120 \mathrm{~kg} / \mathrm{ha}$, which approximately corresponded to $0.9 \mathrm{LU} / \mathrm{ha}$ (LU = livestock unit), 1.4 and $2.0 \mathrm{LU} / \mathrm{ha}$. The first $50 \%$ dose of the cattle slurry (diluted with water in a ratio $1: 3$ ) was applied early in spring and the second $50 \%$ after the first cut. Cow manure was applied in autumn, dung water after the first cut. These organic fertilizers originated from the stables of VÚCHS Rapotín Ltd. (cow manure and dung water) and from the Dairy farm in České Petrovice (cattle slurry). The fertilizers were analysed for the 
content of nutrients before their application, which was conducted annually during 2005-2011.

The plots were cut 2-4 times per year depending on the given dose of fertilizer. Unfertilized plots (F-0) with three types of utilization were also observed as the control treatments: two- (extensive), three- (medium intensive) and four- (intensive) cuts per year. Treatments of the fertilization and cutting regime are given in Table 3.

\section{Experimental measurements}

The proportion of three functional groups (grasses, legumes and forbs) was visually estimated directly in percentages in each plot in May (before the

T

Meteorological data of the experimental site

\begin{tabular}{|c|c|c|c|c|c|c|c|c|c|c|c|c|c|c|c|}
\hline \multirow{3}{*}{ Year } & \multicolumn{12}{|c|}{ Months } & \multirow{2}{*}{\multicolumn{2}{|c|}{ Average }} & \multirow{3}{*}{ Deviation $^{1}$} \\
\hline & Jan. & Feb. & Mar. & Apr. & May & June & July & Aug. & Sept. & Oct. & Nov. & Dec. & & & \\
\hline & \multicolumn{12}{|c|}{ Daily average temperature $\left[{ }^{\circ} \mathrm{C}\right]$} & Annual & $\begin{array}{l}\text { Vegetation } \\
\text { period }\end{array}$ & \\
\hline 2005 & -1.3 & -4.5 & -0.7 & 8.9 & 12.7 & 15.6 & 18.3 & 15.7 & 13.4 & 4.9 & 3.1 & -1.7 & 7.03 & 14.10 & -0.17 \\
\hline 2006 & -8.4 & -2.6 & -1.8 & 9.3 & 11.2 & 15.8 & 19.3 & 14.2 & 12.6 & 7.8 & 4.9 & 1.6 & 6.99 & 13.73 & -0.21 \\
\hline 2007 & 2.4 & 1.8 & 3.3 & 6.9 & 12.9 & 16.8 & 17.0 & 15.8 & 9.5 & 6.3 & 1.0 & -2.0 & 7.64 & 13.15 & 0.44 \\
\hline 2008 & 0.3 & 0.5 & 1.4 & 6.5 & 11.7 & 16.1 & 16.7 & 15.0 & 10.5 & 7.0 & 4.7 & 0.5 & 7.58 & 12.75 & 0.38 \\
\hline 2009 & -5.3 & -1.5 & 2.3 & 8.5 & 11.4 & 14.2 & 16.8 & 16.0 & 12.6 & 6.1 & 4.0 & -1.4 & 6.98 & 13.25 & -0.23 \\
\hline 2010 & -6.2 & -2.6 & 0.9 & 6.2 & 11.4 & 16.3 & 18.9 & 16.0 & 10.1 & 4.4 & 5.4 & -5.8 & 6.25 & 13.15 & -0.95 \\
\hline 2011 & -2.9 & -3.8 & 3.0 & 10.5 & 12.8 & 17.5 & 17.0 & 18.1 & 14.2 & 7.8 & 2.3 & 1.1 & 8.13 & 15.02 & 0.93 \\
\hline \multirow{3}{*}{ Year } & \multicolumn{12}{|c|}{ Months } & \multicolumn{2}{|c|}{ Total } & \multirow{3}{*}{ Deviation $^{1}$} \\
\hline & Jan. & Feb. & Mar & Apr. & May & June & July & Aug. & Sept. & Oct. & Nov. & Dec. & \multirow{2}{*}{ Annual } & \multirow{2}{*}{$\begin{array}{l}\text { Vegetation } \\
\text { period }\end{array}$} & \\
\hline & \multicolumn{12}{|c|}{ Precipitation [mm] } & & & \\
\hline 2005 & 90.0 & 45.0 & 27.5 & 23.5 & 76.0 & 50.0 & 78.0 & 69.0 & 19.0 & 56.0 & 120.0 & 74.6 & 728.6 & 315.5 & 35.6 \\
\hline 2006 & 36.1 & 63.7 & 62.7 & 62.2 & 84.7 & 89.2 & 41.3 & 125.3 & 22.9 & 31.3 & 73.7 & 32.5 & 725.6 & 425.6 & 32.6 \\
\hline 2007 & 85.6 & 47.2 & 40.1 & 4.0 & 66.4 & 61.5 & 86.6 & 68.3 & 67.9 & 35.9 & 67.0 & 39.9 & 670.4 & 354.7 & -22.6 \\
\hline 2008 & 69.4 & 14.3 & 90.9 & 34.2 & 71.1 & 92.9 & 96.4 & 78.3 & 18.6 & 31.0 & 44.3 & 19.8 & 661.2 & 391.5 & -31.8 \\
\hline 2009 & 37.3 & 56.3 & 70.3 & 16.2 & 66.9 & 88.7 & 120.6 & 35.1 & 10.6 & 78.1 & 41.2 & 68.1 & 689.4 & 338.1 & -3.6 \\
\hline 2010 & 62.6 & 45.3 & 28.2 & 25.8 & 176.6 & 68.5 & 135.1 & 128.9 & 93.1 & 5.5 & 73.9 & 54.7 & 898.2 & 628.0 & 205.2 \\
\hline 2011 & 39.8 & 7.7 & 25.0 & 29.5 & 52.0 & 94.0 & 154.0 & 98.1 & 36.1 & 37.2 & 2.0 & 84.0 & 659.4 & 463.7 & -33.6 \\
\hline
\end{tabular}

${ }^{1}$ Deviation from long-term annual average [1961-1990]

$\mathrm{T}$ a

Soil agro-chemical parameters of soil horizons determined in spring 2005

\begin{tabular}{|c|c|c|c|c|c|c|c|c|}
\hline Horizon $^{1}$ & $\mathrm{pH}_{\mathrm{KCl}}$ & $\mathrm{C}_{\mathrm{ox}}[\%]$ & Ratio $(\mathrm{C}: \mathrm{N})$ & $\mathrm{N}_{\text {tot }}[\mathrm{g} / \mathrm{kg}]$ & $\mathrm{P}[\mathrm{mg} / \mathrm{kg}]$ & $\mathrm{K}[\mathrm{mg} / \mathrm{kg}]$ & $\mathrm{Ca}[\mathrm{mg} / \mathrm{kg}]$ & $\mathrm{Mg}[\mathrm{mg} / \mathrm{kg}]$ \\
\hline $\mathrm{Am}$ & 4.63 & 1.34 & 10.0 & 1.34 & 53 & 109 & 1799 & 124 \\
\hline $\mathrm{Bv}$ & 4.60 & 0.73 & 9.5 & 0.77 & 78 & 62 & 1442 & 97 \\
\hline $\mathrm{Bv} / \mathrm{Cc}$ & 4.41 & 0.33 & 8.4 & 0.39 & 27 & 53 & 1753 & 131 \\
\hline $\mathrm{Cc}$ & 4.44 & 0.19 & 10.5 & 0.18 & 29 & 45 & 1875 & 166 \\
\hline
\end{tabular}

$\mathrm{C}_{\mathrm{ox}}$ - oxidizable organic carbon; $\mathrm{N}_{\text {tot }}-$ total nitrogen in soil

${ }^{1}$ Classification system of soil horizons according to IUSS Working Group WRB (2006) 
$\mathrm{T}$ a

Description of treatments with different grassland managements

\begin{tabular}{|c|c|c|c|c|c|c|c|}
\hline Treatment & Fertilization & $\begin{array}{c}\text { Annual dose } \\
\text { of nitrogen } \\
{[\mathrm{kg} / \mathrm{ha}]}\end{array}$ & Application & First cut & $\begin{array}{l}\text { Second } \\
\text { cut }\end{array}$ & Third cut & $\begin{array}{l}\text { Fourth } \\
\text { cut }\end{array}$ \\
\hline F-0-ext & Nil-fertilization & 0 & - & June 15 & Sept. 30 & - & - \\
\hline F-0-med. int. & Nil-fertilization & 0 & - & May 30 & July 30 & Sept. 30 & - \\
\hline F-0-int. & Nil-fertilization & 0 & - & May 15 & June 30 & Aug. 15 & Sept. 15 \\
\hline M-0.9-ext. & $\begin{array}{l}\text { Cow manure }+ \\
\text { dung water }\end{array}$ & 54 & $\begin{array}{l}\text { Cow manure - in autumn; } \\
\text { dung water - after the } 1^{\text {st }} \text { cut }\end{array}$ & June 15 & Sept. 30 & - & - \\
\hline M-1.4-med. int. & $\begin{array}{l}\text { Cow manure }+ \\
\text { dung water }\end{array}$ & 84 & $\begin{array}{l}\text { Cow manure - in autumn; } \\
\text { dung water - after the } 1^{\text {st }} \text { cut }\end{array}$ & May 30 & July 30 & Sept. 30 & - \\
\hline M-2.0-int. & $\begin{array}{l}\text { Cow manure }+ \\
\text { dung water }\end{array}$ & 120 & $\begin{array}{l}\text { Cow manure - in autumn; } \\
\text { dung water }- \text { after the } 1^{\text {st }} \text { cut }\end{array}$ & May 15 & June 30 & Aug. 15 & Sept. 15 \\
\hline S-0.9-ext. & $\begin{array}{c}\text { Cattle slurry } \\
\text { (diluted with } \\
\text { water } 1: 3 \text { ) }\end{array}$ & 54 & $\begin{array}{c}50 \% \text { of dose }- \text { in spring, } 50 \% \\
\text { of dose - after the } 1^{\text {st }} \text { cut }\end{array}$ & June 15 & Sept. 30 & - & - \\
\hline S-1.4-med. int. & $\begin{array}{c}\text { Cattle slurry } \\
\text { (diluted with } \\
\text { water } 1: 3 \text { ) }\end{array}$ & 84 & $\begin{array}{c}50 \% \text { of dose - in spring, } 50 \% \\
\text { of dose - after the } 1^{\text {st }} \text { cut }\end{array}$ & May 30 & July 30 & Sept. 30 & - \\
\hline S-2.0-int. & $\begin{array}{l}\text { Cattle slurry } \\
\text { (diluted with } \\
\text { water } 1: 3 \text { ) }\end{array}$ & 120 & $\begin{array}{c}50 \% \text { of dose }- \text { in spring, } 50 \% \\
\text { of dose }- \text { after the } 1^{\text {st }} \text { cut }\end{array}$ & May 15 & June 30 & Aug. 15 & Sept. 15 \\
\hline
\end{tabular}

first harvest) each year of the study, whereas cover estimates ranged from $0.5 \%$ to $100 \%$.

Dry matter (DM) annual yield and quality of grasslands were also measured. In each plot, the sward was mown by machine leaving a stubble height of approximately $5 \mathrm{~cm}$. The harvested biomass was immediately weighed and the percentage of DM determined in the laboratory after 48 $\mathrm{h}$ of drying at $65^{\circ} \mathrm{C}$. It was then expressed as DM yield in $\mathrm{t} / \mathrm{ha}$. Nutrients in samples collected during the vegetation seasons 2005-2009 depending on the term of the cut were analysed according to Czech State Standard 467092 (Testing methods of feeding-stuffs). Crude protein (CP) was determined by the Kjeldahl procedure using the device Kjeltec Auto Distillation 2200 and ether extract (EE) by the Soxhlet method. The Fibertec System 2023 FiberCap (FOSS Comp.) was used to analyse crude fibre (CF). Ash (A) content was measured gravimetrically by igniting samples in a muffle furnace at $450^{\circ} \mathrm{C}$ for $4 \mathrm{~h}$. The concentration of nitrogen-free extract (NFE) was calculated according to the formula:

$\mathrm{NFE}[\mathrm{g} / \mathrm{kg} \mathrm{DM}]=1000-(\mathrm{CP}+\mathrm{EE}+\mathrm{CF}+\mathrm{A})$. The in-vitro organic matter digestibility (OMD) was determined by the Tilley \& Terry method (1963) modified according to Resch (1991). The energy value (ME - metabolizable energy; NEL net energy of lactation) was predicted by means of the equations officially used in the Czech Republic and the Slovak Republic, which corresponds with the system INRA (Jarrige et al. 1989).

Analysis of variance (ANOVA) and LSD test $(P<0.05)$ was used for the statistical data analysis by means of the software Statistica v. 10 . 


\section{RESULTS AND DISCUSSION}

\section{Functional groups}

Data about the proportion of functional groups (grasses, legumes, forbs) as percentage are given in Table 4. It was found that grassland management had an influence on the botanical composition with some differences being significant $(P<0.05)$. The mean proportion of grasses was positively influenced by cattle slurry application $(53.4 \%)$, compared with fertilization with cow manure + dung water $(48.8 \%)$, and to control $(42.9 \%)$, whereas this percentage significantly increased with decreasing cutting frequency and decreasing doses of fertiliz-

$\mathrm{T}$ a

Botanical composition (\%) over the treatments and years

\begin{tabular}{|c|c|c|c|}
\hline Functional group & Grasses & Legumes & Forbs \\
\hline \multicolumn{4}{|l|}{ Treatments $^{1}$} \\
\hline F-0-ext. & $49.0^{\text {ae }}$ & 1.9 & 49.1 \\
\hline F-0-med. int. & $40.5^{b}$ & 4.5 & 54.9 \\
\hline F-0-int. & $39.2^{\mathrm{b}}$ & 4.2 & 55.9 \\
\hline M-0.9-ext. & $59.6^{\mathrm{c}}$ & 4.1 & 36.2 \\
\hline M-1.4-med. int. & $45.3^{\text {ad }}$ & 10.2 & 44.5 \\
\hline M-2.0-int. & $41.8^{\mathrm{bd}}$ & 10.3 & 47.5 \\
\hline S-0.9-ext. & $63.6^{\mathrm{c}}$ & 1.7 & 34.5 \\
\hline S-1.4-med. int. & $53.2^{\mathrm{e}}$ & 3.9 & 42.6 \\
\hline S-2.0-int. & $43.5^{\text {bd }}$ & 4.7 & 50.1 \\
\hline \multicolumn{4}{|l|}{ Means of fertilization types } \\
\hline (F) nil-fertilization & $42.9^{\mathrm{a}}$ & $3.5^{\mathrm{a}}$ & $53.3^{\mathrm{a}}$ \\
\hline (M) cow manure + dung water & $48.8^{\mathrm{b}}$ & $8.2^{\mathrm{b}}$ & $42.7^{b}$ \\
\hline (S) cattle slurry & $53.4^{\mathrm{c}}$ & $3.4^{\mathrm{a}}$ & $42.7^{\mathrm{b}}$ \\
\hline \multicolumn{4}{|l|}{ Means of intensities of utilization } \\
\hline (ext.) extensive & $57.4^{\mathrm{a}}$ & $2.6^{\mathrm{a}}$ & $39.9^{\mathrm{a}}$ \\
\hline (med. int.) medium intensive & $46.3^{b}$ & $6.2^{\mathrm{b}}$ & $47.3^{\mathrm{b}}$ \\
\hline (int.) intensive & $41.5^{\mathrm{c}}$ & $6.4^{\mathrm{b}}$ & $51.5^{\mathrm{c}}$ \\
\hline \multicolumn{4}{|l|}{ Means of years } \\
\hline 2005 & $51.1^{\mathrm{a}}$ & $14.7^{\mathrm{a}}$ & $34.1^{\mathrm{ab}}$ \\
\hline 2006 & $52.1^{\mathrm{ab}}$ & $11.7^{\mathrm{b}}$ & $35.7^{\mathrm{a}}$ \\
\hline 2007 & $68.8^{\mathrm{c}}$ & $0.8^{\mathrm{c}}$ & $29.8^{b}$ \\
\hline 2008 & $56.2^{\mathrm{b}}$ & $0.5^{\mathrm{c}}$ & $43.3^{\mathrm{c}}$ \\
\hline 2009 & $32.8^{\mathrm{d}}$ & $0.6^{\mathrm{c}}$ & $66.4^{\mathrm{d}}$ \\
\hline 2010 & $37.0^{\mathrm{e}}$ & $1.5^{\mathrm{c}}$ & $60.8^{\mathrm{e}}$ \\
\hline 2011 & $40.6^{\mathrm{e}}$ & $5.6^{\mathrm{d}}$ & $53.6^{\mathrm{f}}$ \\
\hline Factor & \multicolumn{3}{|c|}{$P$ value } \\
\hline Year & $<0.001$ & $<0.001$ & $<0.001$ \\
\hline Fertilization & $<0.001$ & $<0.001$ & $<0.001$ \\
\hline Intensity of utilization & $<0.001$ & $<0.001$ & $<0.001$ \\
\hline Fertilization $\times$ intensity of utilization & 0.011 & 0.073 & 0.076 \\
\hline
\end{tabular}

The values in the same column with different superscript letters are significantly different at $P<0.05$ level for each variable

${ }^{1}$ See Table 3 
ers. In contrast, the unfertilized treatments showed significantly higher proportion of forbs (53.3\%) in the mean of years, and this proportion significantly increased with increasing intensity of utilization (from $39.9 \%$ in the extensive utilization to $51.5 \%$ in the intensive utilization). The mean proportion of legumes was significantly higher in the treatments with application of cow manure + dung-water combined with medium intensive utilization and intensive grassland utilization $(10.2 \%$ and $10.3 \%$, respectively).

As for the results of other studies, Čunderlík et al. (2012) showed the effects of organic fertilizers on the botanical composition at permanent grassland and they found that sward proportion of grasses increased with increasing rates of fertilizers. At manure application, the proportion of grasses was dominant in the first year, but decreased later and the forbs and legumes proportions were increasing, which corresponds to our results, as well.

In contrast to our results, Seihyung et al. (2006) found that the percentage of legumes in the grassland increased with increased application rate of swine slurry. The reason of this finding could be that pig slurry supplied more phosphorus than did cow slurry (Christie 1987) used in our study. On average, the pig slurry is twice as rich in the content of phosphorous as the cattle slurry (Regulation No. 274/1998 of the Ministry of Agriculture), whereas phosphorus has a positive influence on legumes dominance in grasslands as it was proved by studies such as Skládanka and Hrabě (2008), Veselá et al. (2009) or Raus et al. (2012).

The long-term application of organic fertilizers resulted in the significant changes in the sward botanical composition also in the studies of Liu et al. (2010). Elsaesser et al. (2008) investigated the effects of different fertilization systems (organic and mineral fertilizers) on permanent grasslands and found that fertilization with slurry increased the proportions of grasses, whereas farmyard manure increased forbs; the proportion of legumes was increased by PK and by fertilization with slurry with lime. Søegaard et al. (2008) referred that the cattle slurry application decreased the proportion of legume species, increased the grass proportion, but hardly affected the non-leguminous herbs in grasslands.
Some differences in the scientific findings could be caused by different soil-climatic conditions and types of grasslands of the experimental study sites and also by some differences in treatments (e.g. doses of manures, ways of their application, etc.).

\section{Dry matter yield}

Data about DM yields of grasslands by different management, as well as the significance of differences, are given in Table 5. Significantly higher DM yields were found for the fertilized treatments, whereas cow manure + dung water increased DM yield by $51.9 \%$ and cattle slurry by $56.0 \%$, compared with the unfertilized control (4.81 t/ha). Differences between the used types of organic fertilizers (cattle slurry vs. cow manure) on DM yield were not significant within our study; however, we found a slightly higher DM yield in the slurry treatment $(7.51 \mathrm{t} / \mathrm{ha})$ than in the treatment fertilized with the cow manure + dung water $(7.31 \mathrm{t} / \mathrm{ha})$.

An effect of intensity of utilization was also found within our study. In the grasslands utilized extensively (two cuts per year) fertilized with the lowest doses of organic manures, there was found the significantly lower mean DM yield (6.14 t/ha) in contrast to grasslands with medium intensive and intensive utilization (6.82 and $6.68 \mathrm{t} / \mathrm{ha}$, for three and four cuts per year, respectively). This finding is not in agreement with Gruber et al. (2011) or Parsons et al. (2011), who documented that the treatment of four cuts is unfavourable in terms of production, which was explained in relation to phenological development of the swards.

Based on our results, we can state that DM yields were significantly influenced by the level of organic fertilization, which is in accordance with Jong-Won \& Jacob (1997), Seihyung et al. (2006), Samuil et al. (2009) or Müller et al. (2011). Komárek et al. (2005) who investigated the same experiment at two different localities in the Czech Republic (Jevíčko, Vysoké nad Jizerou) also arrived at similar results. In contrast, Szewczyk et al. (2004) found that the addition of organic manure produced no increment in DM yields, which was probably caused by significant changes in the botanical composition.

In our study, DM yields were further influenced by the year. As apparent from Table 1, April 2007 was characterized by an exceptionally low level of 
precipitation $(4.0 \mathrm{~mm})$, which negatively affected spring growth of the plants in our study site. It subsequently resulted not only in the significant decrease of the mean total seasonal DM yield $(4.15 \mathrm{t} / \mathrm{ha})$ but also in the significant decrease of the forage quality (113.8 $\mathrm{g} / \mathrm{kg} \mathrm{DM}$ of CP; $4.68 \mathrm{MJ} / \mathrm{kg} \mathrm{DM}$ of NEL) in this year 2007 (Tables 5 and 6). From Table 4 it is evident that the exceptionally dry year 2007 had an influence also on the botanical composition (significantly higher proposition of grasses to the detriment of forbs), which is in line with Valkó et al. (2012). As published by Kramberger et al. (2014), the amount of annual herbage DM yield correlated highly with the amount of precipitation during the March-August period. This finding is mentioned and described in relation to climatic conditions also in the paper of Criste et al. (2013).

$\mathrm{T}$ a

Dry matter yields of grasslands at different levels of intensity of utilization and fertilization with organic fertilizers

\begin{tabular}{|l|c|}
\hline Treatments $^{1}$ & Dry matter yield [t/ha] \\
\hline F-0-ext. & $4.90^{\mathrm{a}}$ \\
F-0-med. int. & $4.93^{\mathrm{a}}$ \\
F-0-int. & $4.62^{\mathrm{a}}$ \\
M-0.9-ext. & $6.75^{\mathrm{b}}$ \\
M-1.4-med. int. & $7.65^{\mathrm{c}}$ \\
M-2.0-int. & $7.54^{\mathrm{c}}$ \\
S-0.9-ext. & $6.78^{\mathrm{b}}$ \\
S-1.4-med. int. & $7.88^{\mathrm{c}}$ \\
S-2.0-int. & $7.88^{\mathrm{c}}$ \\
\hline Means of fertilization types & \\
\hline (F) Nil-fertilization & $4.81^{\mathrm{a}}$ \\
(M) Cow manure + dung water & $7.31^{\mathrm{b}}$ \\
(S) Cattle slurry & $7.51^{\mathrm{b}}$ \\
\hline Means of intensities of utilization & \\
\hline (ext.) Extensive & $6.14^{\mathrm{a}}$ \\
(med. int.) Medium intensive & $6.82^{\mathrm{b}}$ \\
(int.) Intensive & $6.68^{\mathrm{b}}$ \\
\hline Means of years & \\
\hline 2005 & $6.14^{\mathrm{a}}$ \\
2006 & $6.06^{\mathrm{a}}$ \\
2007 & $4.15^{\mathrm{b}}$ \\
2008 & $7.42^{\mathrm{c}}$ \\
2009 & $6.75^{\mathrm{d}}$ \\
2010 & $7.37^{\mathrm{c}}$ \\
2011 & $7.95^{\mathrm{e}}$ \\
\hline Factor & $P$ value \\
\hline Year & $<0.001$ \\
Fertilization & $<0.001$ \\
Intensity of utilization & $<0.001$ \\
Fertilization $\times$ intensity of utilization & $<0.001$ \\
\hline
\end{tabular}

The values with different superscript letters are significantly different at $P<0.05$ level

${ }^{1}$ See Table 3 


\section{Forage quality}

Regarding the effect of different grassland management on the forage quality (Table 6), we have found in our study the significant increase of the concentration of $\mathrm{CP}$ with increasing intensity of grassland utilization up to $152.1 \mathrm{~g} / \mathrm{kg} \mathrm{DM}$ in the mean of years, whereas grasslands fertilized with cattle slurry showed the significantly higher concentration of CP $(142.9 \mathrm{~g} / \mathrm{kg}$ DM) compared with unfertilized (126.4 g/kg DM). Further, it was found that the extensive grassland utilization significantly affected the increase of the concentration of CF (up

$$
\mathrm{T} \text { a } \mathrm{b} 1 \text { e } 6
$$

Forage quality (content of nutrients in dry matter) of grasslands at different levels of intensity of utilization and fertilization with organic fertilizers

\begin{tabular}{|c|c|c|c|c|c|c|c|c|}
\hline Traits & $\begin{array}{c}\mathrm{CP} \\
{[\mathrm{g} / \mathrm{kg}]}\end{array}$ & $\begin{array}{c}\mathrm{CF} \\
{[\mathrm{g} / \mathrm{kg}]}\end{array}$ & $\begin{array}{c}\mathrm{EE} \\
{[\mathrm{g} / \mathrm{kg}]}\end{array}$ & $\begin{array}{c}\mathrm{A} \\
{[\mathrm{g} / \mathrm{kg}]}\end{array}$ & $\begin{array}{c}\mathrm{NFE} \\
{[\mathrm{g} / \mathrm{kg}]}\end{array}$ & $\begin{array}{c}\text { OMD } \\
{[\%]}\end{array}$ & $\begin{array}{c}\mathrm{ME} \\
{[\mathrm{MJ} / \mathrm{kg}]}\end{array}$ & $\begin{array}{c}\mathrm{NEL} \\
{[\mathrm{MJ} / \mathrm{kg}]}\end{array}$ \\
\hline \multicolumn{9}{|l|}{ Treatments $^{1}$} \\
\hline F-0-ext. & 108.9 & 274.9 & 27.8 & 99.8 & 488.5 & 61.37 & 8.34 & 4.78 \\
\hline F-0-med. int. & 120.8 & 258.1 & 29.8 & 111.5 & 479.8 & 65.07 & 8.84 & 5.13 \\
\hline F-0-int. & 139.4 & 237.9 & 32.2 & 110.6 & 480.0 & 66.83 & 9.17 & 5.36 \\
\hline M-0.9-ext. & 112.6 & 284.1 & 25.7 & 96.8 & 480.9 & 60.65 & 8.11 & 4.62 \\
\hline M-1.4-med. int. & 130.4 & 249.6 & 31.4 & 106.3 & 482.3 & 65.47 & 8.81 & 5.11 \\
\hline M-2.0-int. & 154.9 & 225.9 & 34.8 & 112.0 & 472.3 & 67.73 & 9.12 & 5.32 \\
\hline S-0.9-ext. & 116.2 & 287.1 & 25.8 & 99.3 & 471.6 & 61.05 & 8.16 & 4.66 \\
\hline S-1.4-med. int. & 135.2 & 253.8 & 31.5 & 108.2 & 471.3 & 65.71 & 8.83 & 5.12 \\
\hline S-2.0-int. & 162.0 & 236.2 & 33.7 & 120.1 & 448.0 & 67.76 & 9.02 & 5.26 \\
\hline \multicolumn{9}{|l|}{ Means of fertilization types } \\
\hline (F) Nil-fertilization & $126.4^{\mathrm{a}}$ & 257.0 & 30.4 & 107.3 & 482.8 & 64.42 & 8.78 & 5.09 \\
\hline (M) Cow manure + dung water & $137.4^{b}$ & 253.2 & 31.7 & 105.0 & 478.5 & 64.62 & 8.68 & 5.01 \\
\hline (S) Cattle slurry & $142.9^{b}$ & 259.0 & 31.2 & 109.2 & 463.6 & 64.84 & 8.67 & 5.01 \\
\hline \multicolumn{9}{|l|}{ Means of intensities of utilization } \\
\hline (ext.) Extensive & $112.6^{\mathrm{a}}$ & $282.1^{\mathrm{a}}$ & $26.4^{\mathrm{a}}$ & 98.6 & 480.3 & $61.02^{\mathrm{a}}$ & $8.21^{\mathrm{a}}$ & $4.68^{\mathrm{a}}$ \\
\hline (med. int.) Medium intensive & $128.8^{\mathrm{b}}$ & $253.8^{\mathrm{b}}$ & $30.9^{b}$ & 108.7 & 477.8 & $65.42^{b}$ & $8.83^{b}$ & $5.11^{\mathrm{b}}$ \\
\hline (int.) Intensive & $152.1^{\mathrm{c}}$ & $233.3^{c}$ & $33.6^{\mathrm{c}}$ & 114.2 & 466.7 & $67.44^{\mathrm{b}}$ & $9.11^{\mathrm{b}}$ & $5.31^{\mathrm{b}}$ \\
\hline \multicolumn{9}{|l|}{ Means of years } \\
\hline 2005 & $138.4^{\mathrm{ab}}$ & 256.8 & 28.4 & 100.5 & 480.5 & $66.4^{\mathrm{a}}$ & $8.99^{\mathrm{a}}$ & $5.24^{\mathrm{a}}$ \\
\hline 2006 & $143.8^{\mathrm{ab}}$ & 251.6 & 33.9 & 102.4 & 474.7 & $66.4^{\mathrm{a}}$ & $9.01^{\mathrm{a}}$ & $5.25^{\mathrm{a}}$ \\
\hline 2007 & $113.8^{\mathrm{c}}$ & 269.3 & 31.2 & 112.4 & 478.8 & $62.5^{b}$ & $8.20^{\mathrm{b}}$ & $4.68^{b}$ \\
\hline 2008 & $132.3^{\mathrm{a}}$ & 262.4 & 32.2 & 118.8 & 459.1 & $65.5^{\mathrm{ab}}$ & $8.96^{\mathrm{a}}$ & $5.21^{\mathrm{a}}$ \\
\hline 2009 & $149.4^{b}$ & 242.0 & 29.8 & 101.7 & 481.8 & $65.9^{a}$ & $8.89^{a}$ & $5.16^{\mathrm{a}}$ \\
\hline Factor & \multicolumn{8}{|c|}{$P$ value } \\
\hline Year & $<0.001$ & 0.283 & 0.052 & 0.170 & 0.359 & 0.038 & 0.009 & 0.009 \\
\hline Fertilization & 0.024 & 0.840 & 0.874 & 0.833 & 0.122 & 0.952 & 0.860 & 0.859 \\
\hline Intensity of utilization & $<0.001$ & $<0.001$ & $<0.001$ & 0.089 & 0.283 & $<0.001$ & 0.001 & 0.001 \\
\hline Fertilization $\times$ intensity of utilization & 0.822 & 0.931 & 0.702 & 0.938 & 0.844 & 0.992 & 0.995 & 0.995 \\
\hline
\end{tabular}

The values in the same column with different superscript letters are significantly different at $P<0.05$ level for each variable

${ }^{1}$ See Table 3

Abbreviations: CP - crude protein; $\mathrm{CF}$ - crude fibre; EE - ether extract; A - ash; NFE - nitrogen free extract; OMD - organic matter digestibility; ME - metabolizable energy; NEL - net energy of lactation 
to $282.1 \mathrm{~g} / \mathrm{kg} \mathrm{DM}$ ), the decrease of the concentration of EE (up to $26.4 \mathrm{~g} / \mathrm{kg} \mathrm{DM}$ ) and the decrease of the energy value (up to $8.21 \mathrm{MJ} \mathrm{g} / \mathrm{kg} \mathrm{DM}$ of ME; or up to $4.68 \mathrm{MJ} \mathrm{g} / \mathrm{kg}$ DM of NEL). The OMD was negatively influenced by the extensive grassland utilization $(61.0 \%, 65.42 \%$ and $67.44 \%$ for the extensive, medium intensive and intensive grassland utilization, respectively).

These results about the forage quality are in agreement with Szewczyk et al. (2004), who found that the fertilized (including organic fertilizers) swards produced $55-60 \%$ more protein within their investigations. In the experiment of Vintu et al. (2008), the influence of organic fertilization was investigated on the content of $\mathrm{CP}$, crude fibre, phosphorus and raw ash. The applied fertilization systems resulted in an increased fodder yield and CP content, as compared with the unfertilized control, by $14-29 \%$ on Nardus stricta grassland and by $9-22 \%$ on Agrostis capillaris + Festuca rubra grassland.

Usually, the intensive grassland utilization is connected with the decrease of DM yield by the simultaneous increase of the forage quality (Gruber $e t$ al. 2011). Within our study, it was found that higher doses of organic fertilizers (especially of cattle slurry) by the increasing grassland utilization had more significant effect than the intensity of utilization. Our finding could be explained by the fact that cattle slurry provided a source of fast-release nitrogen, which could be immediately utilized by the plants for their growth. As Cabrera and Gordillo (1995) referred, slurries typically contain more inorganic than organic $\mathrm{N}$, whereas most of the inorganic $\mathrm{N}$ in slurries is present as $\mathrm{N}-\mathrm{NH}_{4}{ }^{+}$.

\section{CONCLUSIONS}

Based on our results, we can conclude that the extensive grassland utilization and the organic fertilizers' application (cattle slurry in particular) significantly affected the increase of the proportion of grasses. The application of cow manure + dung-water together with the intensive and medium intensive grassland utilization positively influenced the proportion of legumes. DM yields were significantly influenced by the year and by the organic fertilization compared with unfertilized controls, whereas the increasing doses of both types of organic fertilizers significantly increased DM yields, even though the treatments with higher doses of fertilizers were utilized more intensively.

Appropriate grassland management through the number of cuts and fertilization makes it possible to improve botanical composition, and amount and quality of the forage. In our study, cattle slurry application significantly increased the concentration of CP in DM compared with unfertilized control. Extensive grassland utilization significantly affected the increase of the concentration of $\mathrm{CF}$, and the decrease the energy value as well as the OMD.

Our findings suggested that medium intensive (three cuts per year) and intensive grassland utilization (four cuts per year) by the fertilization with doses of organic fertilizers, which corresponded to $84 \mathrm{~kg} \mathrm{~N} / \mathrm{ha} /$ year and $120 \mathrm{~kg} \mathrm{~N} / \mathrm{ha} /$ year, respectively, were the most suitable management practices from the viewpoint of animal nutrition. There are other relevant environmental factors that could influence these parameters, including climatic conditions, which are different for each locality and vegetation season. For the specific sites, it is necessary to take into account also the possible environmental risks, which could arise from the application of high doses of organic fertilizers (e.g. decrease of species diversity, leaching of nutrients into ground water).

Acknowledgements. This work was supported by the institutional support for the long-term conceptual development of the research organization, Ministry of Agriculture Decision No. RO1214 from 27 February 2014.

\section{REFERENCES}

CABRERA, M.L. - GORDILLO, R.M. 1995. Nitrogen release from land-applied animal manures. In HATCHER, K.J. (Ed.) Proceedings of the 1995 Georgia Water Resources Conference, University of Georgia, Athens, pp. 175-179. ISBN 0-935835-04-0.

CHRISTIE, P. 1987. Long term effects of slurry on grassland. In VAN DER MEER, H.G. (Ed.) - UNWIN, R.J. - VAN DIJK, T.A. - ENNIK, G.C. - MEER, H.G. Animal manure on grassland and fodder crops. Fertilizer or waste? Dodrecht : Martinus Nijhoff Publishers, pp. 301-304. ISBN 90-247-3568-8.

CRISTE, D. - MIHAI, G. - SIMA, N. - MEDREA, I. BOTIS, A. - SIMA, R. 2013. Studies regarding the 
influence of organic and mineral fertilization on the permanent grassland from Maramures depression Petrova. In Bulletin UASVM Animal Science and Biotechnologies, vol. 70, no. 2, pp. 240-243.

Czech Statistical Office, 2013. Land use in regions [electronic resource]. Data released on 05.08.2013. Available at: http://www.czso.cz/eng/redakce.nsf/i/home.

CZEMBOR, E. 2013. Effects of organic fertilization on agronomic traits of perennial grass species recommended for conventional and low input farming. In Biuletyn Instytutu Hodowli i Aklimatyzacji Roślin, no. 270, pp. 85-107.

ČUNDERLÍK, J. - KIZEKOVÁ, M. 2012. The application of mineral and organic fertilizers and its impact on the quality and production of herbage at semi-natural grassland. In KOVÁČIKOVÁ, Z. (Ed.) - VARGOVÁ, V. - JENDRIŠÁKOVÁ, S. Ecosystems and their functions. Banská Bystrica, Plant Production Research Centre Piešt'any, pp. 108-109. ISBN 978 80-89417-40-7.

DUFFKOVÁ, R. - LIBICHOVÁ, H. 2013. Effects of cattle slurry application on plant species composition of moderately moist Arrhenatherion grassland. In Plant, Soil and Environment, vol. 59, no. 11, pp. 485-491.

ELSAESSER, M. - KUNZ, H.G. - BRIEMLE, G. 2008. Strategy of organic fertilizer use on permanent grassland - results of a 22-year-old experiment on meadow and mowing-pasture. In Grassland Science in Europe, vol. 13 , pp. 580-582.

FOISSY, D. - VIAN, J.F. - DAVID, C. 2013. Managing nutrient in organic farming system: reliance on livestock production for nutrient management of arable farmland. In Organic Agriculture, vol. 3, no. 3-4, pp. 183-199. DOI: 10.1007/s13165-014-0060-8.

GRUBER, L. - SCHAUER, A. - HÄUSLER, J. - URDL, M. - ADELWÖHRER, A. - SÜDEKUM, K.H. 2011. Influence of growth stage of permanent grassland on dry matter yield, nutritive value, feed intake and milk yield of dairy cows during the whole period of vegetation. In Grassland Science in Europe, vol. 16, pp. $136-138$.

IUSS Working Group WRB (2006): World reference base for soil resources 2006. World Soil Resources Reports, No. 103, FAO : Rome. 145 pp. ISBN 92-5105511-4.

JARRIGE, R. 1989. Ruminant nutrition. Paris-London-Rome : John Libbey Eurotext. 389 pp. ISBN 0-86196-247-8.

JONG-WON, R. - JACOB, H. 1997. The effect of cattle slurry on the forage yield and grassland ecosystem. In Journal of the Korean Society of Grassland Science, vol. 17, no. 1, pp. 35-42.

KOMÁREK, P. - KOHOUTEK, A. - FIALA, J. - ODSTRČILOVÁ, V. - NERUŠIL, P. 2005. Produkce a kvalita píce travních porostů v závislosti na zatížení skotem a frekvenci sečení [Production and quality of grassland forage in dependence on cattle load and cutting frequency]. In KOHOUTEK, A. (Ed.) - POZDÍŠEK, J. Kvalita pice z travnich porosti̊, VÚRV Praha-Ruzyně, pp. 175-182. ISBN 80-86555-75-5.
KRAMBERGER, B. - GSELMAN, A. - PODVRŠNIK, M. - LEŠNIK, M. - ŠKORJANC, D. 2014. Effects of low precipitation periods on the herbage yield of mesic semi-natural grasslands under different cutting regimes. In Zemdirbyste-Agriculture, vol. 101, no. 1, pp. 11-18. DOI: 10.13080/z-a.2014.101.002.

LALOR, S.T.J. - HOEKSTRA, N.J. - MURPHY, P.N.C. - RICHARDS, K.G. - LANIGAN, G.J. 2012. Practical advice for slurry application strategies for grassland systems. International Fertilizer Society, 34 pp. ISBN 978-0853103493.

LIU, W. - ZHU, Y.G. - CHRISTIE, P. - LAIDLAW, A.S. 2010. Botanical composition, production and nutrient status of an originally Lolium perenne-dominant cut grass sward receiving long-term manure applications. In Plant and Soil, vol. 326, no. 1-2, pp. 355-367. DOI: $10.1007 / \mathrm{s} 11104-009-0016-z$.

MORAVEC, J. - BALÁTOVÁ-TULÁČKOVÁ, E. - BLAŽKOVÁ, D. - HADAČ, E. - HEJNÝ, S. - HUSÁK, Š. - JENÍK, J. - KOLBEK, J. - KRAHULEC, F. KROPÁČ, Z. - NEUHÄUSL, R. - RYBNÍČEK, K. ŘEHOŘEK, V. - VICHEREK, J. 1995. Rostlinná společenstva České republiky a jejich ohrožení [Red list of plant communities of the Czech Republic and their endangerment]. $2^{\text {nd }} \mathrm{Ed}$, Litoměřice, $206 \mathrm{pp}$. ISBN 80 9000827-6-9.

MÜLLER, M. - HRABĚ, F. - CHROUST, J. 2005. Změny $v$ kvalitě píce pastevního porostu $v$ průběhu pastevního období [Changes in forage quality of pasture sward in course of grazing period]. In KOHOUTEK, A. (Ed.) - POZDÍŠEK, J. Kvalita pice z travnich porosti̊, VÚRV Praha-Ruzyně, pp. 106-111. ISBN 8086555-75-5.

MÜlleR, C. - LAUGHLIN, R. J. - CHRISTIE, P. WATSON, C. J. 2011. Effects of repeated fertilizer and cattle slurry applications over 38 years on $\mathrm{N}$ dynamics in a temperate grassland soil. In Soil Biology \& Biochemistry, vol. 43, no. 6, pp. 1362-1371. DOI: $10.1016 /$ j.soilbio.2011.03.014.

PARSONS, A. - ROWARTH, J. - THORNLEY, J. - NEWTON, P. - LEMAIRE, G. - HODGSON, J. - CHABBI, A. 2011. Primary production of grasslands, herbage accumulation and use, and impacts of climate change. In Grassland productivity and ecosystem services, CABI, Wallingford, pp. 3-18. ISBN 9781845938093. DOI: $10.1079 / 9781845938093.0003$

POZDÍŠEK, J. - ŠTÝBNAROVÁ, M. - KOHOUTEK, A. - SVOZILOVÁ, M. - RŽONCA, J. 2008. Forage quality by animal fertilizer applications and by different grassland management. In Grassland Science in Europe, vol. 13, pp. 498-500.

QUITT, E. 1971. Klimatické oblasti Československa [Climatic regions of Czechoslovakia]. Brno : Geografický ústav ČSAV, $73 \mathrm{pp}$.

RAUS, J. - KNOT, P. - HRABĔ, F. 2012. Effect of fertilization and harvest frequency on floristic composition and yields of meadow stand. In Acta Universitatis Agriculturae et Silviculturae Mendelianae Brunensis, vol. 60, pp. 181-186. DOI: 10.11118/ actaun201260050181. 
Regulation No. 274/1998 of the Ministry of Agriculture on the storage and manner of use of fertilizers.

$\mathrm{RESCH}, \mathrm{R}$. 1991. In vitro - Verdaulichkeitsuntersuchung nach Tilley und Terry, 1963 [In vitro - determination of organic matter digestibility by Tilley and Terry, 1963.] In Bericht über die Tagung der ALVA Fachgruppe Versuchswesen. Innsbruck 22-23. Mai 1991.

SAMUIL, C. - VINTU, V. - IACOB, T. - SAGHIN, G.H - TROFIN, A. 2009. Management of permanent grasslands in North-Eastern Romania. In Grassland Science in Europe, vol. 14, pp. 234-237.

SEBASTIÁ, M.T. 2004. Role of topography and soils in grassland structuring at the landscape and community scales. In Basic and Applied Ecology, vol. 5, no. 4, pp. 331-346. DOI: 10.1016/j.baae.2003.10.001.

SEIHYUNG, Y. - YOUNGCHUL, L. - JONGGEUN, K. EUISOO, J. 2006. The study on the application level of swine slurry in grassland pasture. In Journal of the Korean Society of Grassland Science, vol. 26, no. 2, pp. 63-68.

SKLÁDANKA, J. - HRABĚ, F. 2008: Effect of fertilization and cutting frequency on botanical composition, diversity and grassland quality. In Agriculture (Pol'nohospodárstvo), vol. 54, no. 1, pp. 1-8.

SØEGAARD, K. - ERIKSEN, J. - ASKEGAARD, M. 2008. Herbs in grasslands - effect of slurry and grazing/cutting on species composition. In Grassland Science in Europe, vol. 13, pp. 200-202.

SZEWCZYK, W. - KASPERCZYK, M. - KACORZYK, P. 2004. Role of farmyard manure on upland meadows. In Grassland Science in Europe, vol. 9, pp. 714-716.
TILLEY, J.M.A - TERRY, R.A. 1963. A two stage technique for the in vitro digestion of forage crops. In Grass and Forage Science, vol. 18, no. 2, pp. 104-111. DOI: 10.1111/j.1365-2494.1963.tb00335.x.

TZIALLA, C.E. - VERESOGLOU, D.S. - PAPAKOSTA, D. - MAMOLOS, A.P. 2006. Changes in soil characteristics and plant species composition along a moisture gradient in a Mediterranean pasture. In Journal of Environmental Management, vol. 80, no. 1, pp. 90-98. DOI: 10.1016/j.jenvman.2005.08.017.

VALKÓ, O. - TÖRÖK, P. - MATUS, G. - TOTHMERESZ, B. 2012. Is regular mowing the most appropriate and cost-effective management maintaining diversity and biomass of target forbs in mountain hay meadows? In Flora, vol. 207, no. 4, pp. 303-309. DOI: $10.1016 / \mathrm{j}$. flora.2012.02.003.

VESELÁ, M. - MRKVIČKA, J. - HREVUŠOVÁ, Z. 2009. Species development of meadow stand related to yield. In Grassland Science in Europe, vol. 14, pp. 265-268.

VINTU, V. - SAMUIL, C. - TROFIN, A. - POPOVICI, I.C. 2008. The influence of organic and mineral fertilizers on fodder quality in NE Romania. In Grassland Science in Europe, vol. 13, pp. 637-639.

WELlsteIN, C. - OTTE, A. -WALDHARDT, R. 2007. Impact of site and management on the diversity of central European mesic grassland. In Agriculture, Ecosystems and Environment, vol. 122, no. 2, pp. 203-210. DOI: 10.1016/j.agee.2006.12.033.

Received: June 17, 2014 